\title{
Manuka Honey Induces Apoptosis of Epithelial Cancer Cells through Aquaporin-3 and Calcium Signaling
}

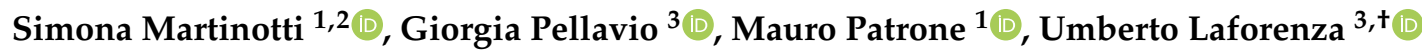 \\ and Elia Ranzato $1,2, *,+(\mathbb{D}$ \\ 1 DiSIT- Dipartimento di Scienze e Innovazione Tecnologica, University of Piemonte Orientale, viale Teresa \\ Michel 11, 15121 Alessandria, Italy; simona.martinotti@uniupo.it (S.M.); mauro.patrone@uniupo.it (M.P.) \\ 2 DiSIT- Dipartimento di Scienze e Innovazione Tecnologica, University of Piemonte Orientale, \\ piazza Sant'Eusebio 5, 13100 Vercelli, Italy \\ 3 Department of Molecular Medicine, Human Physiology Unit, University of Pavia, 27100 Pavia, Italy; \\ giorgia.pellavio01@universitadipavia.it (G.P.); lumberto@unipv.it (U.L.) \\ * Correspondence: elia.ranzato@uniupo.it; Tel.: +39-0131-360260; Fax: +39-0131-360243 \\ + These authors contributed equally to this work.
}

Received: 7 October 2020; Accepted: 25 October 2020; Published: 27 October 2020

\begin{abstract}
Honey is a natural product with a long use in traditional medicine and is well recognized to regulate different biological events. It is an important source of various biological or pharmacological molecules and, therefore, there is a strong interest to explore their properties. Evidence is growing that honey may have the potential to be an anticancer agent acting through several mechanisms. Here we observed for the first time in a cancer cell line a possible mechanism through which honey could induce an alteration in the intracellular reactive oxygen species and homeostatic balance of intracellular calcium concentration leading to cell death by apoptosis. This mechanism seems to be enhanced by manuka honey's ability to maintain high $\mathrm{H}_{2} \mathrm{O}_{2}$ permeability through aquaporin-3.
\end{abstract}

Keywords: AQP3; $\mathrm{Ca}^{2+}$ signaling; honey; manuka; $\mathrm{ROS}$

\section{Introduction}

Honey, achieved from nectar collected by honey bees, is a combination of carbohydrates, proteins, fatty acids, minerals and vitamins containing several classes of phytochemicals with a high flavonoid content and the presence of phenolic compounds [1].

Honey has been utilized for a long time as a traditional remedy and one of the ancient known utilizations is for the healing of wounds. Honey antibacterial activity has been well defined in the literature and some intrinsic characteristics of honey such as acidity and high osmolarity as well as the occurrence of flavonoids and phenolic acids are recognized as important for these activities [1].

Moreover, there is a growing number of widespread scientific and clinical indications to suggest honey use for wound healing and tissue repair [1-3].

In addition to its antibacterial and wound promoting abilities, recent data have underlined multiple roles for honey in inflammatory cytokines release by macrophages [4], neutrophil migration stimulation [5], cell proliferation inhibition and apoptosis induction as well as the arrest of cell cycle [6] and lipoprotein oxidation inhibition [7].

More recently, research has revealed that honey, with its richness in flavonoids and polyphenols, shows antiproliferative properties against tumor cell lines [6-8].

Nevertheless, its antitumor mechanisms are still to be completely explained. A few pathways through which natural honey could produce its antitumor properties have been proposed such as 
permeabilization of the mitochondrial outer membrane, arrest of the cell cycle, apoptosis induction and oxidative stress modulation [9].

Aquaporins are transmembrane proteins originally recognized as water channels in all organisms and then found to show multiple substrate specificity, such as hydrogen peroxide $\left(\mathrm{H}_{2} \mathrm{O}_{2}\right)[10,11]$.

We have already demonstrated that honey is able to produce $\mathrm{H}_{2} \mathrm{O}_{2}$ [2] and in keratinocytes, a specific aquaporin (i.e., aquaporin-3) helps the passive $\mathrm{H}_{2} \mathrm{O}_{2}$ diffusion across the biological membranes [2]. The $\mathrm{H}_{2} \mathrm{O}_{2}$ mediated transport through aquaporin-3 (AQP3) is of physiological prominence for downstream cellular signaling pathways such as the intracellular $\mathrm{Ca}^{2+}$ signals onset $[12,13]$.

Here, we describe a mechanism through which manuka honey induces an alteration in the intracellular ROS and homeostatic balance of $\left[\mathrm{Ca}^{2+}\right]_{\mathrm{i}}$ leading to cell death by apoptosis in a cancer cell line. This mechanism is enhanced by manuka honey's ability to maintain high $\mathrm{H}_{2} \mathrm{O}_{2}$ permeability through AQP3.

These results raise our knowledge and could be advantageous for honey application as a therapeutic candidate for targeting tumor cells.

\section{Materials and Methods}

\subsection{Honey Sample}

Honey specimens of diverse floral origin, i.e., manuka (UMF, Unique Manuka Factor, 15+, $250 \mathrm{mg} / \mathrm{kg}$ methylglyoxal, 250+ MGO) buckwheat and acacia less than 12 months old were received from Yamada Apiculture Center, Inc. (Tomata-gun, Okayama, Japan). Raw honeys were maintained at room temperature in the dark. A stock honey solution was arranged by dissolving in a warmed DMEM (Dulbecco's Modified Eagle's medium) or loading buffer and $0.22 \mu \mathrm{m}$ sterilized. Honey preparations were freshly made before each experiment.

\subsection{Cell Culture and Reagents}

All reagents, if not specified, were bought from Mercks/Sigma-Aldrich.

A431 cells (derived from an epidermal carcinoma of the vulva taken from an 85 year old female) were maintained at $5 \% \mathrm{CO}_{2}, 37^{\circ} \mathrm{C}$, in $4.5 \mathrm{~g} / \mathrm{L}$ (high glucose) DMEM complemented with streptomycin $(100 \mathrm{mg} / \mathrm{mL}), 10 \% \mathrm{FBS}$, penicillin $(100 \mathrm{U} / \mathrm{mL})$ and L-glutamine $(200 \mathrm{mM})$ (FBS, Euroclone, Milan, Italy) [14].

\subsection{Calcein-Am Assay}

The cell viability assay was executed by using calcein-acetoxymethylester (Calcein-AM), a nonfluorescent, lipophilic dye. Calcein-AM enters the cells and is converted to hydrophilic fluorescent dye in the cytoplasm by intracellular esterases. A431 cells seeded in 96-well plates were exposed for $24 \mathrm{~h}$ to honey as specified, then PBS-washed and maintained at $37^{\circ} \mathrm{C}$ for half an hour with a probe (Calcein-Am prepared in PBS, $2.5 \mu \mathrm{M}$ ). Fluorescence values were then obtained with a multimode reader (Infinite 200 Pro, Tecan, Wien, Austria) with the use of a $485 \mathrm{~nm}$ excitation filter and a $535 \mathrm{~nm}$ emission filter.

\subsection{Apoptosis Assay}

Apoptosis induction with honey in A431 cells was assessed by a multi-parameter apoptosis assay kit (catalog \#600330, Cayman Chemicals Company, Ann Arbor, MI, USA). Cells seeded in 96-well plates were exposed for $3 \mathrm{~h}$ to honey as specified and analyzed using a multimode reader (Infinite 200 Pro, Tecan). 


\subsection{Free Cytosolic $\mathrm{Ca}^{2+}$ Concentration $\left(\left[\mathrm{Ca}^{2+}\right]_{i}\right)$ Measurements}

Cells, seeded and settled down overnight on glass-based dishes (Iwaki Glass, Inc., Tokyo, Japan), were loaded in the dark at $37^{\circ} \mathrm{C}$ for $30 \mathrm{~min}$ with $20 \mathrm{mM}$ Fluo-3/AM, a fluorescent, cell-permeant calcium probe. A loading buffer consisting of $(\mathrm{mM}) 1 \mathrm{MgCl}_{2}, 5 \mathrm{KCl}, 10$ glucose, $2 \mathrm{CaCl}_{2}, 140 \mathrm{NaCl}$ and $10 \mathrm{ph} 7.4$ HEPES was utilized. To perform experiments avoiding the presence of $\mathrm{Ca}^{2+}\left(0 \mathrm{Ca}^{2+}\right.$ condition), the ion was absent from the confocal buffer [14-17]. Cells were then analyzed with a time-lapse setting, utilizing a confocal apparatus (Zeiss LSM 510 system) equipped with an inverted microscope (Carl Zeiss Microscopy GmbH, Jena, Germany).

Excitation was produced by an argon source $(488 \mathrm{~nm})$ and the emission was gathered by a broad bandpass filter. To reduce the Fluo-3 bleaching, the laser power was reduced to $1 \%$. Cells were observed with a $20 \times$ Zeiss objective ( $0.5 \mathrm{NA})$. Fluo-3 fluorescence was measured using the ROI-mean tool of the Zeiss software.

The calibration of Fluo-3 probe was realized using this approach [18]:

$$
\mathrm{Ca}^{2+}=\mathrm{Kd}(\mathrm{F}-\mathrm{Fmin}) /(\mathrm{Fmax}-\mathrm{F})
$$

where $\mathrm{Kd}$ is $400 \mathrm{nmol} / \mathrm{L}$.

Fmax and Fmin are respectively the maximum and minimum of fluorescence levels gained by Fluo-3 after $500 \mu \mathrm{M}$ A23187 (calcium ionophore) exposure followed by a $20 \mathrm{mM}$ EDTA addition.

\subsection{Polymerase Chain Reaction (PCR)}

After cell exposure to the designated experiment settings, a commercial kit was used to collect and purify total RNA (NucleoSpin RNAII Kit from Macherey-Nagel, Düren, Germany). cDNA was created with a specific cDNA kit (from Roche Diagnostics, Transcriptor First Strand cDNA Synthesis Kit). Quantitative reverse transcriptase PCR (qRT-PCR) was realized using a Sybr green mastermix (Ambion Inc, Austin, TX, USA) and a panel of primers (KiCqStart ${ }^{\circledR}$ SYBR ${ }^{\circledR}$ Green Primers; Table 1) by means of a PCR machine (CFX384 Real-Time machine from Bio-Rad Laboratories, Hercules, CA, USA). A $\Delta \Delta \mathrm{Ct}$ method was utilized to calculate the gene expression.

Table 1. Primers sequences utilized for quantitative reverse transcriptase PCR (qRT-PCR).

\begin{tabular}{ccc}
\hline Target Gene & Forward Sequences & Reverse Sequences \\
\hline AQP9 & $5^{\prime}$-ATTGGGATCCACTTCACTG-3' & $5^{\prime}$-AGTGGACTGTGAACTTCC-3' \\
\hline AQP5 & $5^{\prime}$-GCTGGCACTCTGCATCTTCGC-3' & $5^{\prime}$-AGGTAGAAGTAAAGGATGGCAGC-3' \\
\hline AQP4 & $5^{\prime}$-GCTGTGATTCCAAACGGACTGATC-3' & $5^{\prime}$-CTGACTCCTGTTGTCCTCCACCTC-3' \\
\hline AQP3 & $5^{\prime}$-CTGTGTATGTGTATGTCTGC-3' & $5^{\prime}$-TTATGACCTGACTTCACTCC-3' \\
\hline AQP1 & $5^{\prime}$-TAAGGAGAGGAAAGTTCCAG-3' & $5^{\prime}$-AAAGGCAGACATACACATAC-3' \\
\hline -actin & $5^{\prime}$-TCCCTGGAGAAGAGCTACGA-3' & $5^{\prime}$-AGCACTGTGTTGGCGTACAG-3' \\
\hline GADPH & $5^{\prime}$-AATCCCATCACCATCTTCCA-3' & $5^{\prime}$-TGGACTCCACGACGTACTCA-3' \\
\hline
\end{tabular}

\subsection{Immunoblotting}

A431 cell cultures were homogenized using a RIPA buffer additioned with a phosphatase and protease inhibition mixture. Homogenates were treated at $80{ }^{\circ} \mathrm{C}$ for $10 \mathrm{~min}$ in a Laemmli buffer [19]. A total of $30 \mu \mathrm{g}$ proteins were electrophorized on a precast polyacrylamide gel (4-20\% Mini-PROTEAN TGX Stain-Free Gels, Bio-Rad Laboratories) and a PVDF membrane was blotted by using a Trans-Blot Turbo Transfer Pack (Bio-Rad Laboratories) with a specific transfer system (Bio-Rad Laboratories).

To prevent non-specific protein binding, PVDF membranes were blocked using a blocking solution consisting of Tris buffered saline solution (TBS) prepared with 5\% skimmed milk and $0.1 \%$ Tween. 
Membranes were then probed for one hour or overnight with a rabbit anti-AQP3 antibody (SAB5200111 with a dilution of 1:1000) and a RabMAb anti-beta-2-microglobulin antibody (EP2978Y) Abcam, product number: ab75853 with a dilution of 1:10,000) diluted in the TBS and $0.1 \%$ Tween. After washing, the membranes were exposed for at least $1 \mathrm{~h}$ with a goat antirabbit secondary antibody conjugated with peroxidase (AP132P; Millipore, with a dilution of 1:100,000) prepared in a blocking solution. The bands were visualized by incubating with western blotting revealing apparatus (CYANAGEN, Italy). To approximate the band molecular weights, pre-stained molecular weight markers (ab116028, Abcam) were utilized. Blots were scanned with an Expression 1680 Pro scanner system (Epson Corp., Long Beach, CA, USA). The bands were quantified by densitometry (Amersham) and the outcomes indicated as a densitometric ratio of AQP3/B2M.

\subsection{RNA Interference}

The N-ter Nanoparticle approach was used to transfect cells with $5 \mu \mathrm{M}$ siRNA oligonucleotides, or with equimolar scrambled siRNA. We utilized commercial siRNA sequences specific to the human AQP3 (see Table 2). Commercial non-targeting siRNA (siRNA Universal Negative Control) was utilized for scrambled siRNA experiments. Transfected cells were harvested after $24 \mathrm{~h}$ and utilized for the designated tests.

Table 2. siRNA oligonucleotide sequences.

\begin{tabular}{ccc}
\hline Protein Target & Forward Sequence & Reverse Sequence \\
\hline AQP3 & $5^{\prime}$-GAGCAGAUCUGAGUGGGCA-3' & $5^{\prime}$-UGCCCACUCAGAUCUGCUC-3' \\
\hline
\end{tabular}

\subsection{Intracellular ROS Measurement}

The level of ROS present in the cells was evaluated utilizing dihydrorhodamine (DHR)-123, a fluorescent dye precursor, transformed to fluorescent rhodamine 123 upon interaction with ROS. Cells seeded in 96-well plates were loaded at room temperature in the dark for half an hour with DHR-123 $(30 \mu \mathrm{M})$ in a loading buffer as described for the confocal microscopy experiment. After incubation, cells were washed with a loading buffer and the fluorescence was measured with a multimode reader (Infinite 200 Pro, Tecan) by using a $485 \mathrm{~nm}$ excitation filter and a $530 \mathrm{~nm}$ emission filter. ROS production observations were indicated as arbitrary units of fluorescence [20].

\subsection{Water Permeability Measures}

Osmotic water permeability of A431 cells was assessed by a stopped-flow light scattering method as already defined [21].

Water transport was assessed in (a) control, untreated cells, (b) cells exposed to $50 \mu \mathrm{M} \mathrm{H}_{2} \mathrm{O}_{2}$ for $45 \mathrm{~min}$ and (c) cells treated with $4 \%$ manuka honey for $45 \mathrm{~min}$. The iso-osmolarity of control and $\mathrm{H}_{2} \mathrm{O}_{2}$-treated cells was obtained by adding $4 \%$ artificial honey [2] ( $3 \mathrm{~g}$ saccharose, $11.17 \mathrm{~g}$ glucose, $13.5 \mathrm{~g}$ fructose and $5.7 \mathrm{~mL}$ water) to the incubation media.

\subsection{Statistical Analysis}

Statistics were made with GraphPad Prism 8 (GraphPad Software Inc, San Diego, CA, USA). Based on the data, one-way or two-way ANOVAs were utilized and the required corrections (Tukey's test, Bonferroni correction, Dunnet post-test and Newman-Keuls $Q$ test) were subsequently applied. Statistical details of each experiment (test used, value of $n$, replicates, $p$ value, etc.) can be found in the Figure legends. 


\section{Results}

\subsection{Cell Viability}

We evaluated honey cytotoxicity by using a Calcein-Am end-point on A431 cells, an epidermoid carcinoma cell line. We used three different kind of honeys such as acacia, buckwheat and manuka, as shown in Table 3.

Table 3. Effective concentrations values, $\mathrm{EC}_{05}$ and $\mathrm{EC}_{50}(\% \mathrm{v} / \mathrm{v})$, resulting from dose-response curves for the three honeys on A431 cells at $24 \mathrm{~h}$.

\begin{tabular}{ccc}
\hline Honey & EC $_{\mathbf{0 5}}$ & EC $_{\mathbf{5 0}}$ \\
\hline Acacia & $2.36 \%(1.68-3.32 \%)$ & $5.84 \%(5.33-6.39 \%)$ \\
Buckwheat & $1.05 \%(0.67-1.69 \%)$ & $3.78 \%(3.41-4.19 \%)$ \\
Manuka & $0.66 \%(0.48-0.92 \%)$ & $2.59 \%(2.36-2.85 \%)$ \\
\hline
\end{tabular}

Experiments were performed by the Calcein-Am method in triplicate with a minimum of eight replicates each. $95 \%$ CIs are indicated in parenthesis. Am, acetoxymethylester; CI, confidence interval; EC, effective concentration.

According to the cell viability assay results, we performed the subsequent experiments only with manuka honey, which was the most cytotoxic one.

\subsection{Intracellular $\mathrm{Ca}^{2+}$ Variations}

We started to examine if manuka honey was capable of producing alterations in $\left[\mathrm{Ca}^{2+}\right]_{\mathrm{i}}$. Accordingly, we measured variations in intracellular $\mathrm{Ca}^{2+}$ induced after honey treatment by means of time-lapse confocal microscopy imaging of A431 cells preloaded with Fluo-3/AM, a fluorescent $\mathrm{Ca}^{2+}$ probe.

We observed that the $\left[\mathrm{Ca}^{2+}\right]_{\mathrm{i}}$ sampled at $5 \mathrm{~s}$ intervals (Figure $1 \mathrm{~A}$ ) and at $0.5 \mathrm{~s}$ intervals (Figure 2A) did not experience in control conditions any spontaneous oscillations.

We analyzed $\left[\mathrm{Ca}^{2+}\right]_{\mathrm{i}}$ variations of A431 cells exposed to a range of increasing concentrations $(1,2$, 3,4 and $5 \% \mathrm{v} / \mathrm{v}$ ) of manuka honey, observing a dose-dependent increase in the $\left[\mathrm{Ca}^{2+}\right]_{\mathrm{i},}$ (Figure 1).

The recorded traces showed that from 1 to $3 \%$, manuka honey induced a non-significant peak that returned to a plateau phase comparable with control conditions (Figure 1A,B). Conversely, 4 and $5 \%$ manuka honey determined a consistent $\left[\mathrm{Ca}^{2+}\right]_{i}$ peak that was not able to return to a homeostatic plateau phase (Figure 1A,B). In particular, as shown in Figure 1C, in these conditions, the peak and the plateau phases were not significantly different, indicating an altered calcium homeostasis.

Considering the incompatibility with cell survival of the treatment with $5 \%$ manuka honey, despite the short observation time we decided to perform the following $\mathrm{Ca}^{2+}$ signals recording only with $4 \%$ manuka honey.

Moreover, to highlight the importance of the presence of honey for the maintenance of the altered plateau phase, we performed an observation treating cells with manuka honey after $60 \mathrm{~s}$ as in the other experiments. Immediately after reaching the peak phase, we then removed the honey treatment, replacing this with only a loading buffer. We observed that the absence of honey in the medium determined a significant decrease in the $\left[\mathrm{Ca}^{2+}\right]_{i}$ that reached control values immediately after the removal of honey (Figure $2 \mathrm{~B}$ ). 

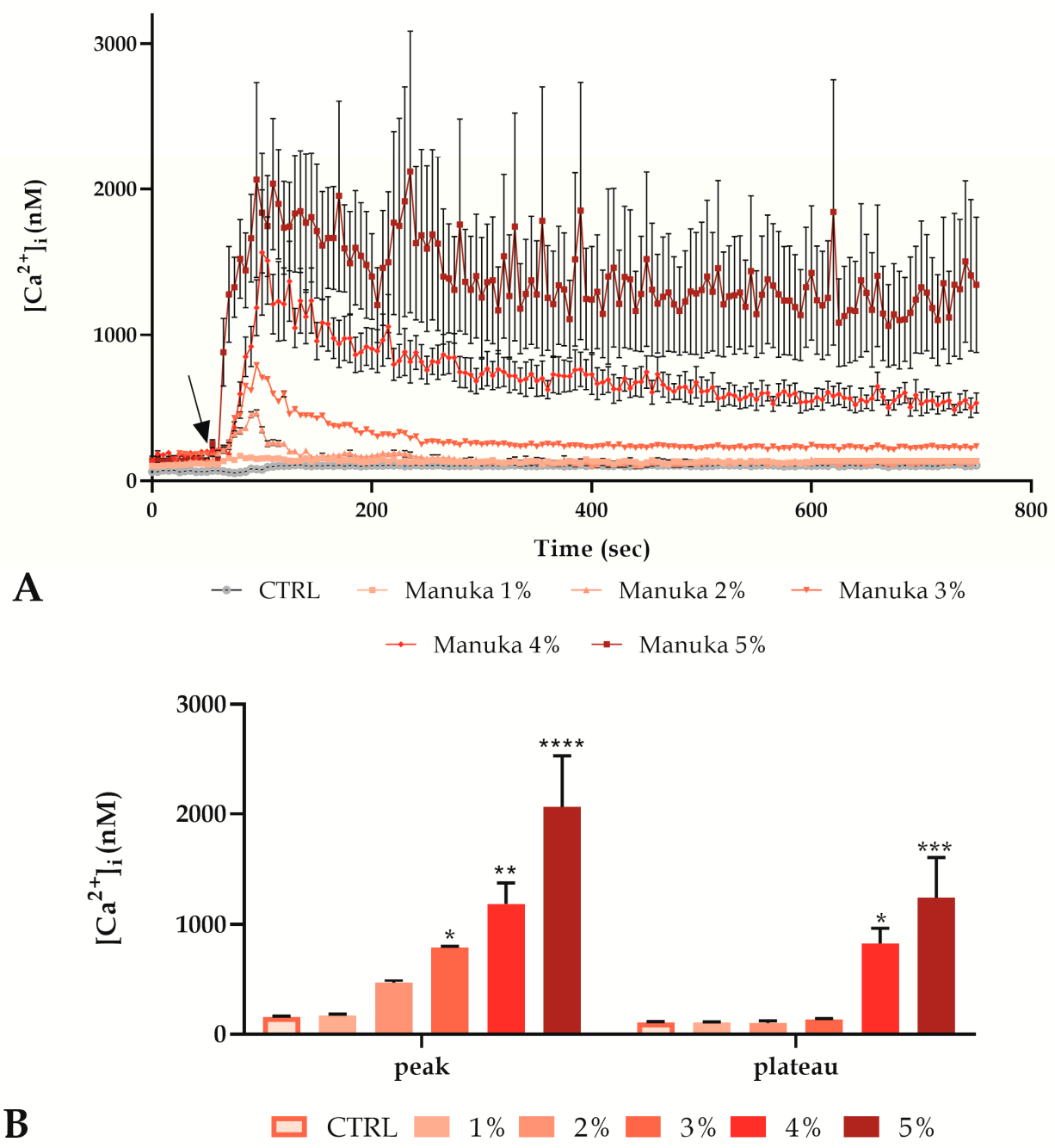

B

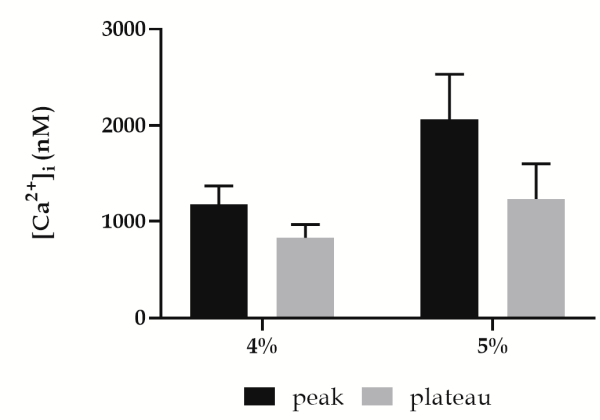

Figure 1. Manuka honey determined an intracellular $\mathrm{Ca}^{2+}$ concentration increase in A431 cells in a dose-dependent manner. (A) $\left[\mathrm{Ca}^{2+}\right]_{\mathrm{i}}$ variations assessed at $5 \mathrm{~s}$ intervals displaying no alterations in control conditions and dose-dependent configurations of $\mathrm{Ca}^{2+}$ signaling after treatment with different manuka honey concentrations, i.e., 1, 2, 3, 4 and 5\% v/v. The arrow shows the honey addition after $60 \mathrm{~s}$. Data are mean $\pm \mathrm{SEM}$ of $\left[\mathrm{Ca}^{2+}\right]_{i}$ traces assessed in different cells. Sample size: for each concentration, 40 cells from 3 exp. (B) $\left[\mathrm{Ca}^{2+}\right]_{\mathrm{i}}$ variations expressed as mean \pm SEM of the peak or plateau of $\mathrm{Ca}^{2+}$ responses stimulated by treatment with different concentrations. Number of cells as previously indicated. Asterisks on bars indicate the statistical differences between CTRL and other conditions determined by two-way ANOVA followed by Tukey's post-test $\left({ }^{* * * *} p<0.0001,{ }^{* * *} p<0.001,{ }^{* * *} p<0.01\right.$, $\left.{ }^{*} p<0.05\right)$. (C) Comparison of $\left[\mathrm{Ca}^{2+}\right]_{\mathrm{i}}$ variations expressed as mean $\pm \mathrm{SEM}$ of the peak and plateau of $\mathrm{Ca}^{2+}$ responses stimulated by treatment with 4 or $5 \% \mathrm{v} / \mathrm{v}$. Sample size as previous indicated. Statistics obtained by two-way ANOVA followed by Bonferroni correction. 


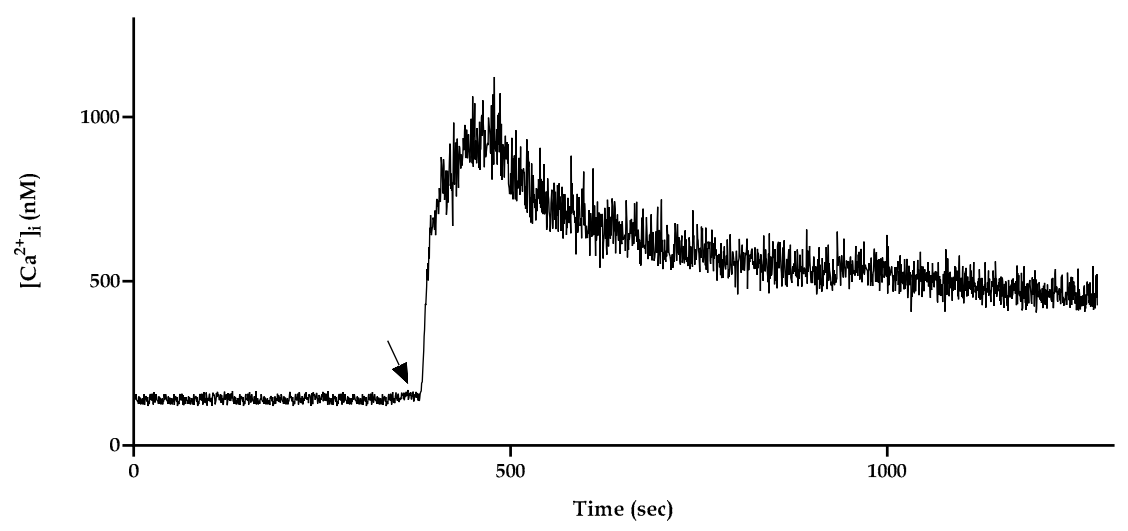

A

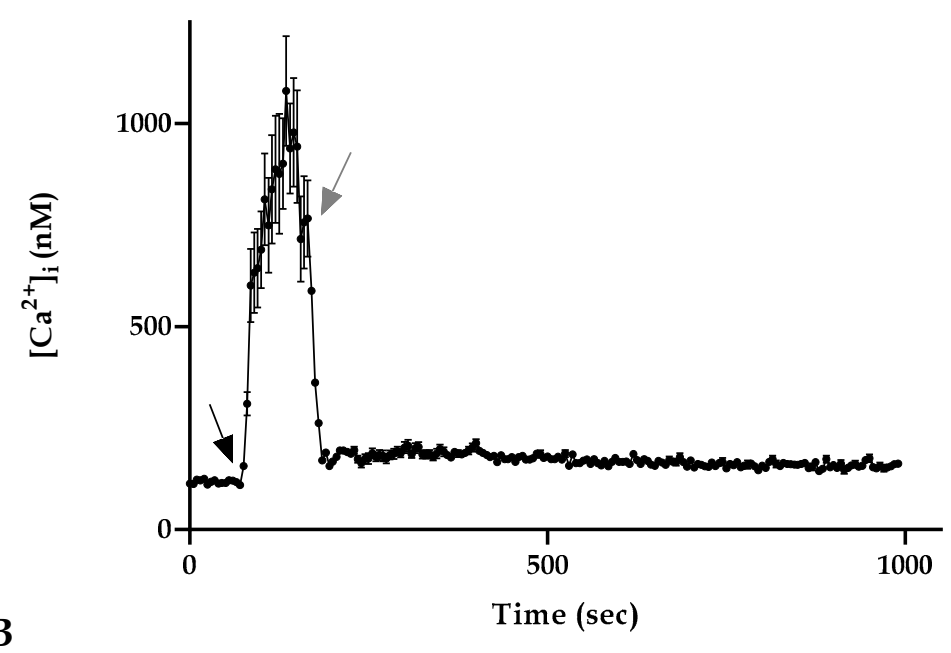

Figure 2. Characterization of the manuka honey induced $\mathrm{Ca}^{2+}$ increase in A431 cells. (A) $\left[\mathrm{Ca}^{2+}\right]_{\mathrm{i}}$ variations recorded at $0.5 \mathrm{~s}$ intervals induced by $4 \%$ manuka honey. Data are mean of $\left[\mathrm{Ca}^{2+}\right]_{\mathrm{i}}$ traces recorded in 40 different cells. (B) To monitor the role of honey in inducing a $\left[\mathrm{Ca}^{2+}\right]_{\mathrm{i}}$ increase, A431 cells were stimulated with $4 \%$ manuka honey (black arrow) and then the honey treatment was removed (gray arrow). When honey was removed from the medium, there was a $\left[\mathrm{Ca}^{2+}\right]_{\mathrm{i}}$ decrease. Data are mean \pm SEM of $\left[\mathrm{Ca}^{2+}\right]_{\mathrm{i}}$ traces recorded in 40 different cells from 3 exp.

\subsection{Origin of $\mathrm{Ca}^{2+}$ and $\mathrm{Ca}^{2+}$ Toolkit Involvement}

We repeated the previous experiment in a $0 \mathrm{Ca}^{2+}$ condition (i.e., the absence of $\mathrm{Ca}^{2+}$ from the extracellular space) and the result showed the disappearance of the $\mathrm{Ca}^{2+}$ peak after $4 \%$ manuka honey exposure but a slightly increase in the plateau phase. (Figure 3A). To remark the need for the presence of calcium in the extracellular space, we performed an observation treating cells with manuka honey. Immediately after the peak phase, we then maintained honey treatment but in a $0 \mathrm{Ca}^{2+}$ condition. We noticed that the absence of extracellular calcium determined a gradual decrease in the $\left[\mathrm{Ca}^{2+}\right]_{\mathrm{i}}$ reaching control values (Figure 3B). 


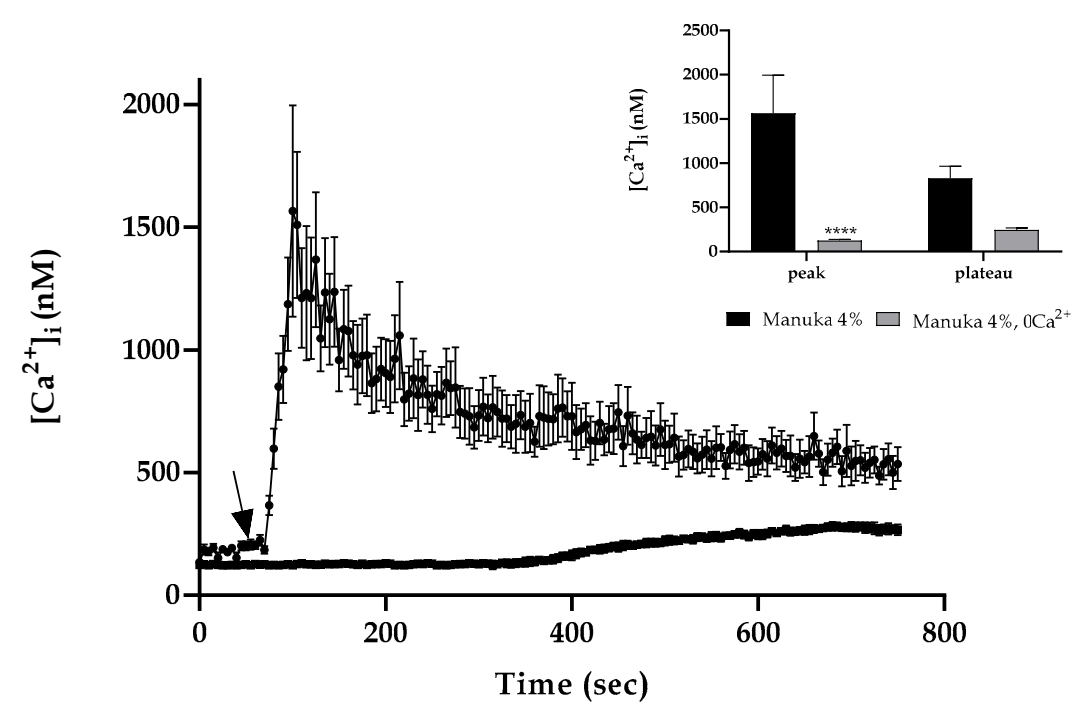

A

$\rightarrow$ Manuka $4 \% \rightarrow$ Manuka $4 \%, 0 \mathrm{Ca}^{2+}$

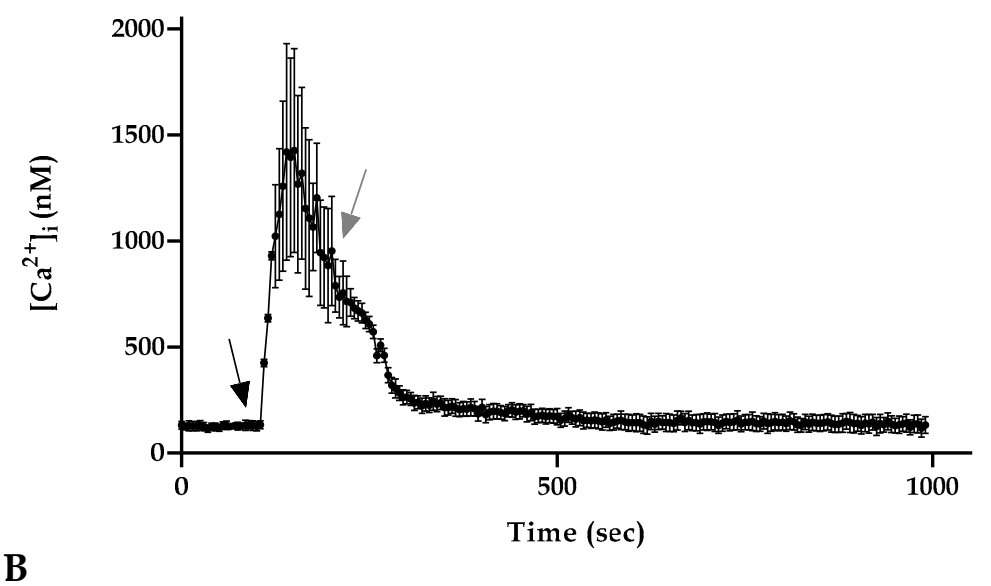

Figure 3. The $\mathrm{Ca}^{2+}$ response to honey involved extracellular $\mathrm{Ca}^{2+}$ entry. (A) $\mathrm{The}^{2 a^{2+}}$ signaling due to $4 \%$ manuka honey exposure was eliminated in a $0 \mathrm{Ca}^{2+}$ condition. The arrow shows the honey addition after $60 \mathrm{~s}$. Data are expressed as mean $\pm \mathrm{SEM}$ of $\left[\mathrm{Ca}^{2+}\right]_{\mathrm{i}}$ traces documented in different cells. Number of cells: manuka honey $0 \mathrm{Ca}^{2+}: 30$ cells from 3 exp; manuka honey: 40 cells from 3 exp; Insert. Mean \pm SEM of the peak $\mathrm{Ca}^{2+}$ response measured under the chosen treatments. Number of cells as in A. Asterisks on bars indicate the statistical differences determined by two-way ANOVA followed by Bonferroni correction $\left({ }^{* * * *} p<0.0001\right)$. (B) A431 cells have been stimulated with $4 \%$ manuka honey in the presence then in the absence of external $\mathrm{Ca}^{2+}\left(0 \mathrm{Ca}^{2+}\right)$. When $\mathrm{Ca}^{2+}$ was removed from the medium there was a $\left[\mathrm{Ca}^{2+}\right]_{\mathrm{i}}$ decrease. The black arrow indicates the addition of honey after $60 \mathrm{~s}$; the gray arrow the removal of extracellular $\mathrm{Ca}^{2+}$. Data are expressed as mean $\pm \mathrm{SEM}$ of $\left[\mathrm{Ca}^{2+}\right]_{\mathrm{i}}$ traces documented in 40 diverse cells from 3 exp.

These results highlighted that extracellular $\mathrm{Ca}^{2+}$ entry showed a crucial role in the $\left[\mathrm{Ca}^{2+}\right]_{\mathrm{i}}$ rise in A431 cells treated with manuka honey.

To further evaluate the involvement of $\mathrm{Ca}^{2+}$ entry from extracellular space, we performed the experiment in the presence of $4 \%$ manuka honey and econazole, a TRPM2 inhibitor (10 $\mu \mathrm{M}, 30 \mathrm{~min}$ pre-incubation). Confocal imaging showed that the inhibitor presence was able to abrogate the $\mathrm{Ca}^{2+}$ peak after $4 \%$ manuka honey exposure but we recorded in the second part of the observation a subsequent small calcium increase as previously detected in a $0 \mathrm{Ca}^{2+}$ condition (Figure $4 \mathrm{~A}$ ). 


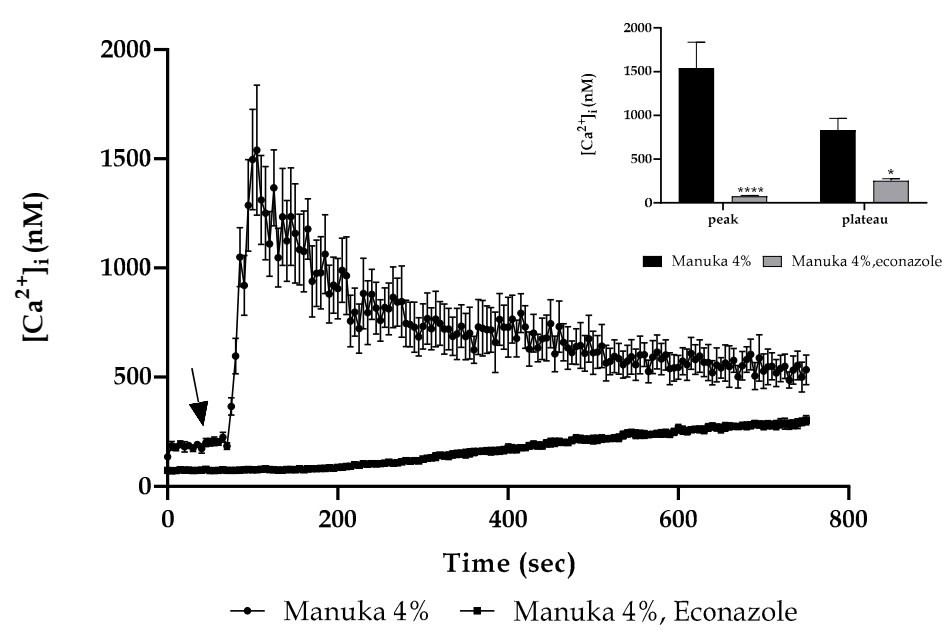

A

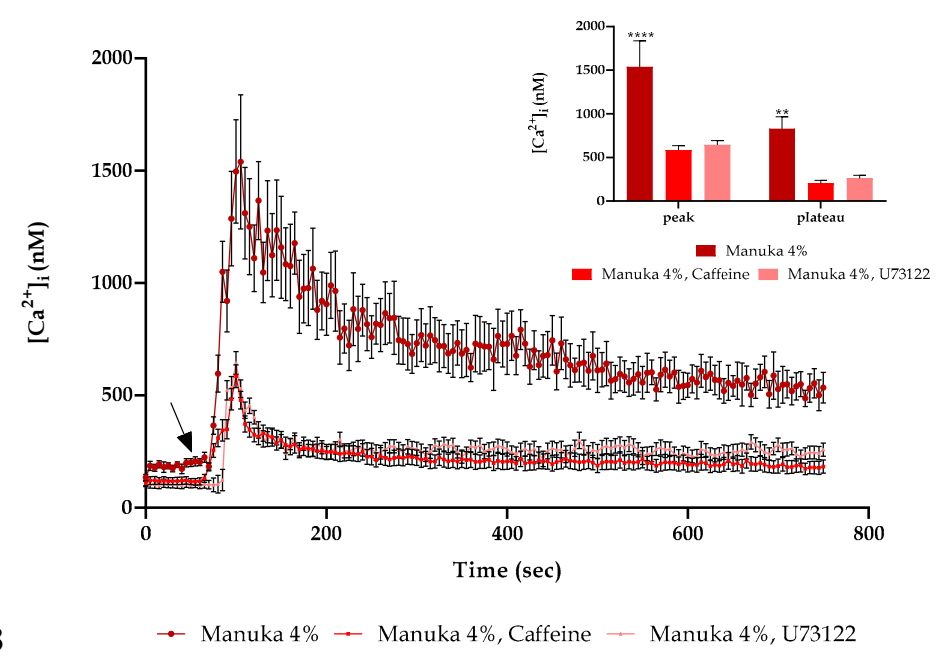

Figure 4. $\mathrm{Ca}^{2+}$ toolkit involvement. (A) The $\mathrm{Ca}^{2+}$ signaling response due to $4 \%$ manuka honey was significantly reduced in the presence of econazole (10 $\mu \mathrm{M}, 30 \mathrm{~min}$ pre-incubation). The arrow shows the honey addition after $60 \mathrm{~s}$. Data are mean \pm SEM of $\left[\mathrm{Ca}^{2+}\right]_{\mathrm{i}}$ traces assessed in different cells. Sample size: manuka honey + econazole: 40 cells from 3 exp; manuka honey: 40 cells from 3 exp. Insert. Mean \pm SEM of the peak $\mathrm{Ca}^{2+}$ response measured under the chosen treatments. Number of cells as in A. Asterisks on bars indicate the statistical differences determined by two-way ANOVA followed by Bonferroni correction ( ${ }^{* * *} p<0.0001,{ }^{*} p<0.05$ ). (B) The $\mathrm{Ca}^{2+}$ response to $4 \%$ manuka honey was reduced in the presence of U73122 (10 $\mu \mathrm{M}, 30 \mathrm{~min}$ pre-incubation) and caffeine $(10 \mathrm{mM}, 30 \mathrm{~min}$ pre-incubation). The arrow specifies honey addition after $60 \mathrm{~s}$. Data are mean $\pm \mathrm{SEM}$ of $\left[\mathrm{Ca}^{2+}\right]_{\mathrm{i}}$ traces measured in cells. Number of cells: manuka honey: 40 cells from 3 exp; manuka honey + U73122: 40 cells from 3 exp; manuka honey + caffeine: 40 cells from 3 exp. Insert. Mean \pm SEM of the peak $\mathrm{Ca}^{2+}$ response measured under the indicated treatments. Sample size as in B. Asterisks as in insert A $\left({ }^{* * * *} p<0.0001,{ }^{* *} p<0.01\right)$.

Furthermore, we utilized two inhibitors of the $\mathrm{IP}_{3}$ signaling pathway, i.e., U73122, a PLC inhibitor [14] (10 $\mathrm{M}$, $30 \mathrm{~min}$ pre-incubation) and caffeine, a blocker of $\mathrm{IP}_{3} \mathrm{R}$ [15] (10 $\mathrm{mM}, 30 \mathrm{~min}$ pre-incubation). In both conditions we observed a decrease of about 2.5 time of the $\mathrm{Ca}^{2+}$ peak (Figure 4B).

\subsection{Apoptosis Induction}

Based on cell viability results and calcium homeostasis alteration observations, we assessed the induction of apoptosis evaluating with a TMRE probe the mitochondrial membrane potential $(\Delta \psi \mathrm{M})$. 
After manuka honey treatment, we observed a significant reduction of $\Delta \psi \mathrm{M}$ highlighting a strong dose-dependent induction of cell death (Figure 5A). This result was also confirmed with the evaluation of the Annexin $\mathrm{V}$ positivity (Figure $5 \mathrm{~B}$ ). As the reduction of $\Delta \psi \mathrm{M}$ is known to produce an increase in the ROS level in the cytosolic milieu, we also evaluated by means of the DHR-123 probe the variation of intracellular ROS after treatment with $4 \%$ manuka honey. As in Figure 5C, after 45 min of exposure we detected a doubling of the fluorescence value.

A
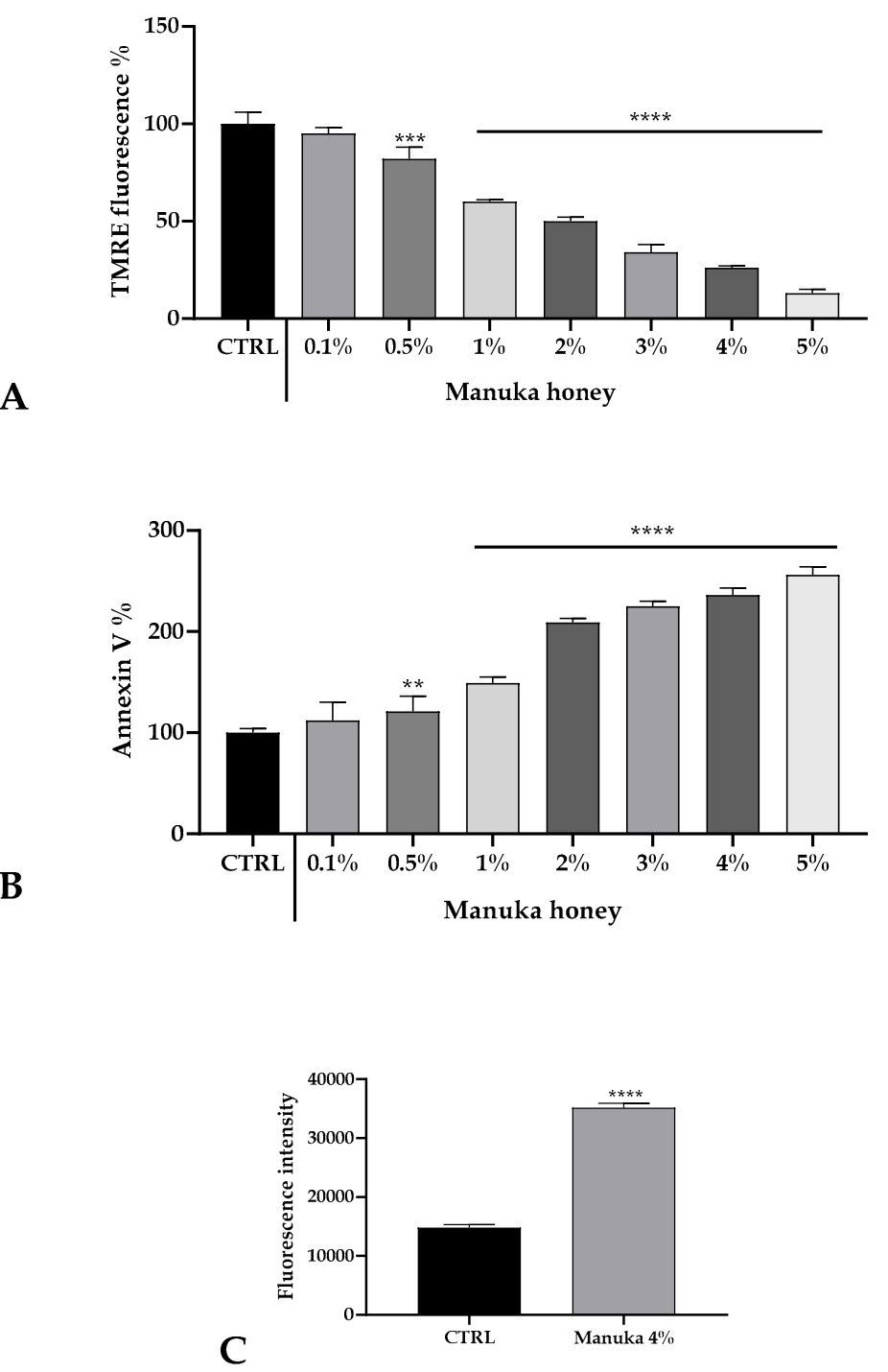

Figure 5. Honey induced cell death of A431 cells. (A) TMRE fluorescence evaluated in A431 cells treated for $3 \mathrm{~h}$ with varying concentrations of manuka honey. Data are expressed as mean $\pm \mathrm{SD}$ obtained from 10 independent treatments and indicated as fluorescence $\%$. Asterisks on bars indicate statistically significant differences assessed by one-way ANOVA followed by a Dunnet post-test ${ }^{* *} p<0.01$, **** $p<0.0001$ ). (B) Annexin V-FITC fluorescence in A431 cells treated with honey as above. Data are mean \pm SD obtained from 10 independent treatments and expressed as fluorescence $\%$. Statistics as in A $\left(^{* * *} p<0.001,{ }^{* * * *} p<0.0001\right)$. (C) Fluorescence values recorded after 45 min incubation with $4 \%$ manuka honey. Data are indicated as mean \pm SD of DHR-123 fluorescence measured in arbitrary units; $\mathrm{n}=16$ microplate wells from two experiments. Different asterisks on bars specify statistical differences determined by a $t$-test $\left.{ }^{* * * *} p<0.0001\right)$. 


\subsection{ROS Involvement in the Mechanism of Action of Manuka Honey}

It is known that honey induces the production of $\mathrm{H}_{2} \mathrm{O}_{2}$ in the extracellular medium [1] and that the extracellular presence of this species is fundamental for the biological honey mechanism of action [2]. Furthermore, we repeated the confocal observation of A431 cells under 4\% manuka honey in the presence of catalase (CAT, 500U). We observed that CAT acts as "scavenger" for free radicals produced by honey and therefore drastically abrogates the $\left[\mathrm{Ca}^{2+}\right]_{i}$ rise (Figure $6 \mathrm{~A}$ ). Accordingly, $\mathrm{H}_{2} \mathrm{O}_{2}$ is the most suitable candidate to induce $\mathrm{Ca}^{2+}$ signaling after manuka honey exposure.

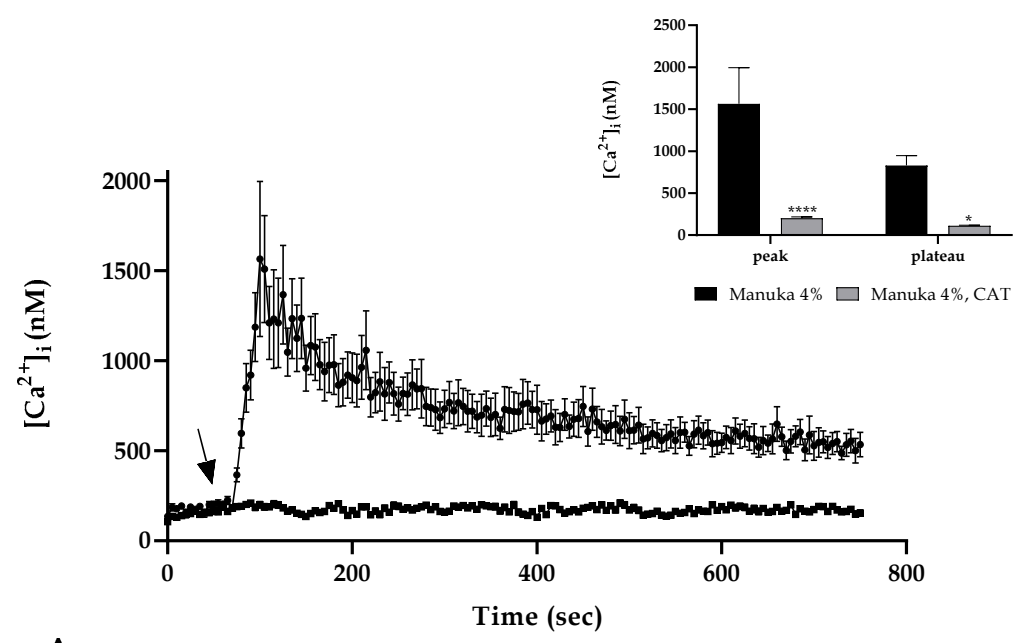

A

- Manuka 4\% Manuka 4\%, CAT
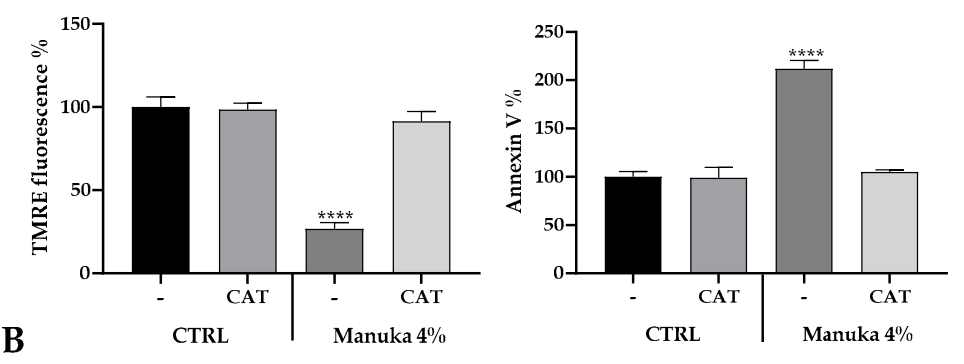

Figure 6. ROS involvement in the manuka honey mechanism of action. (A) The $\mathrm{Ca}^{2+}$ signaling due to $4 \%$ manuka honey was completely abrogated by treatment with Catalase (CAT 500U, $30 \mathrm{~min}$ pre-incubation). Data are indicated as mean $\pm \mathrm{SEM}$ of $\left[\mathrm{Ca}^{2+}\right]_{\mathrm{i}}$ traces measured in different cells. The arrow shows manuka honey addition after $60 \mathrm{~s}$. Sample size: manuka honey + CAT: 40 cells from 3 exp; manuka honey: 40 cells from 3 exp. Insert. Mean $\pm \mathrm{SEM}$ of the $\mathrm{Ca}^{2+}$ peak response measured under the indicated honey exposures. Sample size as in A. Asterisks on bars specify statistical changes determined by Two-way ANOVA followed by Bonferroni correction $\left({ }^{* * * *} p<0.0001,{ }^{*} p<0.05\right)$. (B) TMRE fluorescence (left panel) and Annexin V-FITC fluorescence (right panel) measured in A431 cells treated with $4 \%$ manuka honey plus or not 500U CAT. Data are expressed as mean \pm SD obtained from 10 independent experiments and expressed as fluorescence $\%$. Asterisks on bars show statistically significant changes evaluated by one-way ANOVA followed by Bonferroni correction $\left(^{* * * *} p<0.0001\right)$.

Starting from this result, we performed again the cytotoxicity assay treating cells with an increasing range of manuka honey concentrations after $\mathrm{CAT}$ pretreatment. The $\mathrm{EC}_{50}$ value was $10.23 \%$ (confidence interval (CI) $8.84-11.83 \%)$. 
Moreover, to understand if extracellular $\mathrm{H}_{2} \mathrm{O}_{2}$ is fundamental in the apoptosis induction, we evaluated again the variation of $\triangle \psi \mathrm{M}$ after manuka honey treatment in presence or not of CAT. We observed a significant reduction of $\Delta \psi \mathrm{M}$ only in the absence of CAT while honey plus CAT did not determine any significant variation with respect to untreated cells, highlighting the pivotal role played by ROS in the induction of apoptosis. This result was also validated evaluating the Annexin $\mathrm{V}$ positivity (Figure 6B).

\subsection{Role of Aquaporins ( $A Q P S$ ) in Honey Toxicity}

We have already demonstrated that aquaporins (AQPs) are able to mediate the passage of $\mathrm{H}_{2} \mathrm{O}_{2}$ from extracellular space to cytosol during honey and propolis exposure [2,22]. In particular, we have demonstrated the role of AQP3 in intracellular ROS level increases.

To this aim, we have quantified the basal expression of some AQPs in A431 cells and their variations upon manuka honey exposure (Figure 7). For these experiments, we utilized a honey concentration of $2 \%$, which resulted in the highest not toxic concentration based on confocal calcium recordings. Only the AQP3 expression was improved after honey treatment.

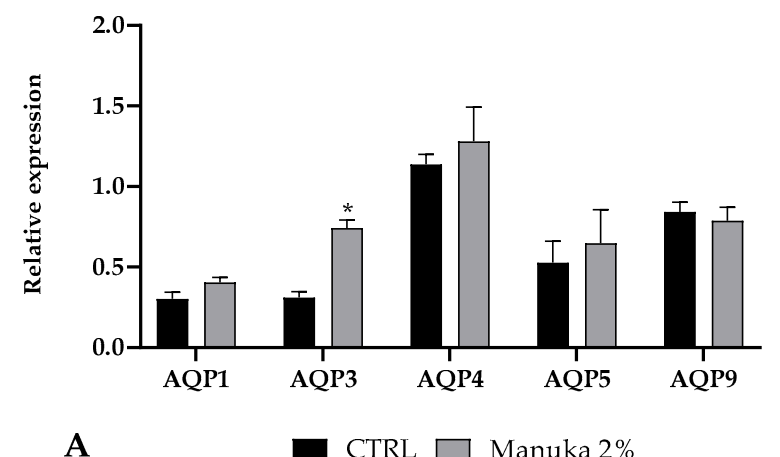

A

- CTRL $\square$ Manuka 2\%

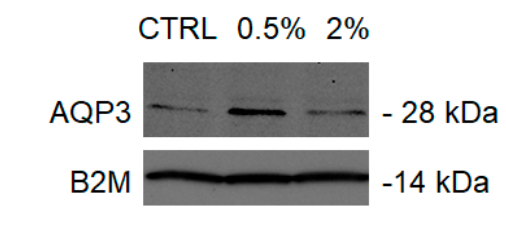

B

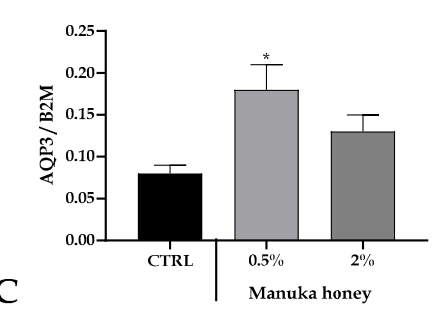

Figure 7. Expression of aquaporins (AQPs) in A431 cells. (A) Expression of AQP genes in A431 cells treated with $2 \%$ manuka honey. The mRNA level of AQPs was assessed by qRT-PCR and is expressed as mean relative expression $\pm \mathrm{SD}(\mathrm{n}=3)$. Asterisk above the bar indicates statistical changes assessed by two-way ANOVA followed by Bonferroni correction $\left({ }^{*} p<0.05\right)$. (B,C) Aquaporin-3 (AQP3) protein expression in A431 cells after manuka honey treatment ( 0.5 and $2 \%)$. CTRL is control condition. Blots illustrative of three were presented. Lanes were loaded with $30 \mu \mathrm{g}$ of proteins, probed with an anti-AQP3 rabbit antibody as defined in the Materials and Methods section. The same blots were stripped and re-incubated with an anti-beta-2-microglobulin (B2M) antibody as housekeeping. A main band of about $28 \mathrm{kDa}$ was shown for AQP3.

To evaluate the mechanism supported by AQP3 in manuka honey induced toxicity, we accomplished the Calcein-Am assay after silencing by RNAi of AQP3 (Figure 8A,B). The results showed that $\mathrm{EC}_{50}$ for scrambled cells was $3.56 \%$ (CI 2.58-4.37\%) while for AQP3-siRNA cells it was $9.19 \%$ (CI 7.16-11.8\%), endorsing the pivotal role of AQP3 in mediating cytotoxicity in A431 cells. 


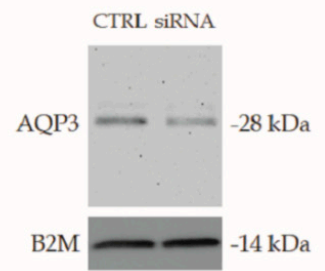

A

E

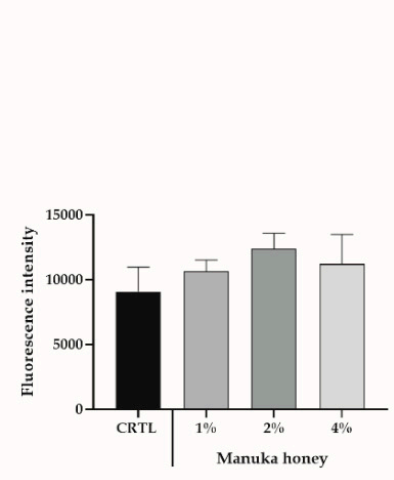

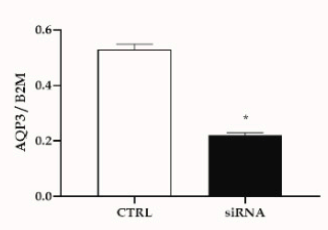

B

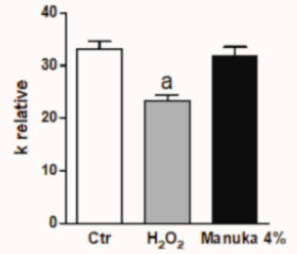

C

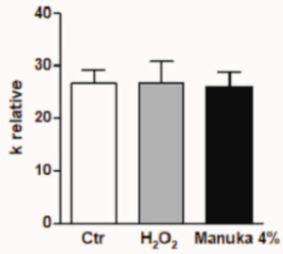

D

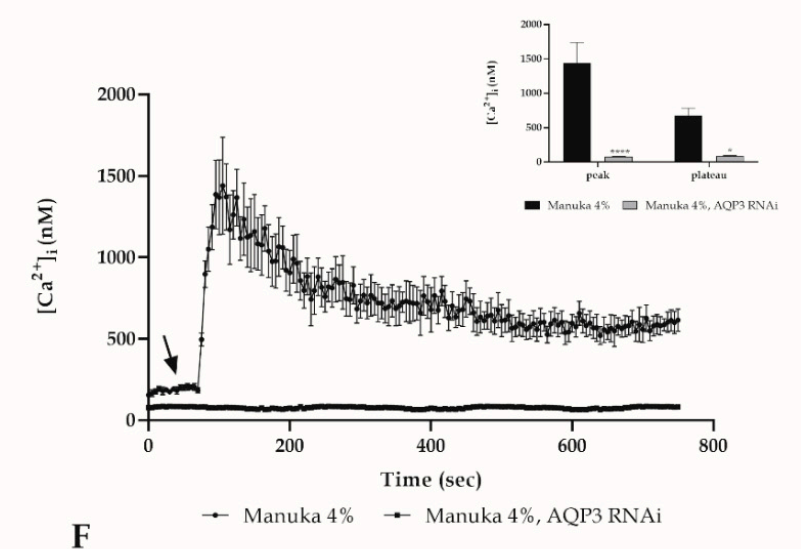

F

Figure 8. Pivotal role of AQP3 in mediating manuka honey cytotoxicity in A431 cells. (A,B) AQP3 protein levels in A431 cells in control conditions (CTRL) or after AQP3 RNAi (siRNA) treatment. Blots illustrative of three were presented. $30 \mu \mathrm{g}$ of proteins were loaded for each lane then probed with an anti-AQP3 antibody and processed as specified in the Materials and Methods section. The same blots were then stripped and incubated with an antibody against anti-beta-2-microglobulin (B2M) as housekeeping (* $p$ $<0.001$, $t$-test). (C,D) Effect of $\mathrm{H}_{2} \mathrm{O}_{2}$ and $4 \%$ Manuka on the water osmotic permeability of A431 cells wild type and AQP3-KO. Cells were exposed to a 150 mOsm osmotic gradient in three different settings: untreated cells (Ctr), cells treated with $50 \mathrm{mM} \mathrm{H}_{2} \mathrm{O}_{2}$ for $45 \mathrm{~min}$ and treated with $4 \%$ manuka honey for $45 \mathrm{~min}$. Bars indicate the osmotic water permeability of A431 cells expressed as a k relative. Values are expressed as mean \pm SEM of 4-15 single shots for each of four different experiments. $p<0.05$ vs. Ctr and Manuka $4 \%$ (ANOVA followed by a Newman-Keuls $Q$ test). (E). Fluorescence values assessed at $10 \mathrm{~min}$ in silenced (RNAi AQP3) cells, incubated with increasing manuka honey concentrations (1, 2 and $4 \%$ ). Data are shown as mean \pm SD of rhodamine 123 fluorescence expressed in arbitrary units; $\mathrm{n}=16$ micro-plate wells from two different experiments. Statistics determined by one-way ANOVA followed by a Dunnet post-test. (F). The $\mathrm{Ca}^{2+}$ response to $4 \% \mathrm{v} / \mathrm{v}$ manuka honey was inhibited in A431 cells transfected with the RNAi selectively targeting AQP3. The arrow specifies the addition of honey after $60 \mathrm{~s}$. Data are indicated as mean $\pm \mathrm{SEM}$ of $\left[\mathrm{Ca}^{2+}\right]_{\mathrm{i}}$ traces recorded in different cells. Number of cells: manuka honey + siRNA: 40 cells from 3 exp; manuka honey: 40 cells from 3 exp. Insert. Mean \pm SEM of the peak $\mathrm{Ca}^{2+}$ response recorded under the designated treatments. Number of cells as in D. Asterisks on bars indicate statistically different changes assessed by two-way ANOVA followed by Bonferroni correction $\left({ }^{* * *} p<0.0001,{ }^{*} p<0.05\right)$.

Moreover, we assessed if AQP3 was the mediator of the $\mathrm{H}_{2} \mathrm{O}_{2}$ entry able to increase intracellular ROS. By using a stopped-flow light scattering technique, we determined the osmotic water permeability of A431 cells, which is an index to the $\mathrm{H}_{2} \mathrm{O}_{2}$ permeability. The results show that the presence of $50 \mathrm{M}$ $\mathrm{H}_{2} \mathrm{O}_{2}$ (a concentration similar to that obtained by honey treatment) reduced significantly the AQP permeability while, with manuka honey, the permeability was unaltered with respect to the control condition. These data support the involvement of AQP3 in the entrance of $\mathrm{H}_{2} \mathrm{O}_{2}$ into the cells and that one or more substances present in the manuka honey were able to maintain the pore completely open even with high concentrations of $\mathrm{H}_{2} \mathrm{O}_{2}$ (Figure $8 \mathrm{C}, \mathrm{D}$ ). Furthermore, we evaluated, by means of a DHR-123 probe, the generation of intracellular ROS after the addition of the $4 \%$ manuka honey that 
was abrogated in the presence of AQP3 RNAi (Figure 8E). Likewise, after honey exposure, the rapid increase in $\left[\mathrm{Ca}^{2+}\right]_{i}$ was completely erased upon RNAi silencing of AQP3 (Figure 8F).

\section{Discussion}

A tumor is one of the most shared reasons of death and is a significant health burden [20] and the number of new tumor cases per year is estimated to rise. Neoplastic condition is still a challenge even with the growing research on its prevention and cure. During the last years, classic methods for cancer treatment have showed severe negative effects. Therefore, researchers were fascinated towards less toxic approaches and novel procedures.

There is, therefore, an augmented awareness for complementary and alternative medicine practice for a huge number of conditions from acute to chronic and deadly diseases [23]. Furthermore, there has been better attention on chemo-preventive and chemo-therapeutic agents derived from food or natural products [24]. The relative safety of food-derived compounds [25] makes them a very interesting and alternative approach compared with classic tumor therapies.

Honeys among natural products are the most investigated for their possible antitumor properties [23]. A few authors have highlighted that honey may support the basis for the growth of novel therapeutics for patients with tumor and tumor-related conditions. Jungle honeys showed the induction of chemotaxis for neutrophils and ROS production, demonstrating its anticancer activity [5]. Recent works on some human tumor cells such as cervical, breast, oral and osteosarcoma [26-28] using Malaysian jungle honey displayed significant antitumor activity. Honey has also showed to possess anticancer properties in vivo and in vitro in an experimental bladder model [28].

Honey contains a huge amount of phytochemicals such as high flavonoid and phenolic content, which contribute to its action [1]. Honey contains sugars, proteins, organic acids, vitamins, phenolic and volatile compounds. The chemical volatile composition of honey is of great importance for influencing its organoleptic properties. Among these volatile compounds we can consider aldehydes, alcohols, esters, ketones, benzene derivatives, nitrogen containing compounds and carboxylic acids. Currently, more than several hundred volatile molecules have been recognized in honeys of diverse botanical origins [23,25].

A few differences in honey efficacy are due its various floral sources as well as floral sources may possess different active molecules. Manuka honey has recently gained attention for its biological activities particularly for its antioxidant and antibacterial capacities. A few observations sustain manuka honey utilization in skin regenerative medicine [1,2,29]. Another interesting component of manuka honey is methylglyoxal (MGO). This compound, normally formed during the Maillard reaction, has been recognized as an important contributor to the non-peroxide antibacterial activity of manuka honey [1].

Buckwheat honey shows a characteristic dark color and its antioxidant ability is well known [1]. Buckwheat honey MGO content is much lower than manuka honey. The pungent odor of buckwheat honey and its dark color may be mainly ascribed to its high mineral content. However, buckwheat honey holds phenolic compounds higher content than manuka honey [30].

The mechanism on how honey can promote an anticancer effect is of great interest. To this aim, we tested on A431, a cancer cell line, the cytotoxicity of three honey types characterized by different concentrations of polyphenolic compounds. We observed a growing cytotoxic effect as well from acacia $<$ buckwheat $<$ manuka honey, so we decided to use only manuka honey for the experiments and characterizations.

We have already tested the cytotoxicity of honeys on an epidermal non-cancerous cell line, i.e., a HaCaT cell line [2,29], which showed a lower toxicity than observed with the A431 cell line, especially highlighted by the $\mathrm{EC}_{05}$ values. On $\mathrm{HaCaT}$ cells, $24 \mathrm{~h}$ manuka honey treatment stimulated cells to allow a faster closure of the wound bed [29]. By contrast, in A431 cells, manuka honey determined the induction of apoptosis after only $3 \mathrm{~h}$ treatment. 
Moving on to disclose the honey mechanism of action on tumor cells, we started evaluating the intracellular $\mathrm{Ca}^{2+}$ homeostasis by means of time-lapse confocal imaging. In the control condition, we did not observe any variation but following honey treatment we recorded a dose-dependent increase of the $\left[\mathrm{Ca}^{2+}\right]_{i}$ followed by a sustained plateau trend only in the case of higher concentrations of the manuka honey treatment. In these conditions, unlike what happened after lower concentration exposure, the homeostatic $\left[\mathrm{Ca}^{2+}\right]_{i}$ was not reached again, showing a behavior not compatible with cell survival.

To better characterize $\mathrm{Ca}^{2+}$ signaling occurring after manuka honey treatment, we decided to carry on a battery of subsequent experiments only with the concentration of $4 \% \mathrm{v} / \mathrm{v}$, which was the most effective concentration compatible with the acquisition timing.

$\mathrm{Ca}^{2+}$ signaling in non-excitable cells includes the release of $\mathrm{Ca}^{2+}$ from intracellular stores and across the plasma membrane. The activation of the $\mathrm{Ca}^{2+}$ entry as well as the activation of $\mathrm{Ca}^{2+}$ pumps and the inhibition of passive $\mathrm{Ca}^{2+}$ pathways maintain homeostatic free cytosolic $\mathrm{Ca}^{2+}$ concentrations. In these kinds of cells, it is known that activation of PLC-mediated signaling pathways determines the release of $\mathrm{Ca}^{2+}$ from intracellular stores [31].

As cited above, the effect of honey on cells was carried out through the action of the $\mathrm{H}_{2} \mathrm{O}_{2}$ produced in the extracellular space [2]. Pretreatment with $500 \mathrm{U}$ of catalase (CAT) completely abolished the $\mathrm{Ca}^{2+}$ rise, suggesting a pivotal role of ROS species to trigger the $\mathrm{Ca}^{2+}$ response. To unveil the origin of the increase of $\left[\mathrm{Ca}^{2+}\right]_{\mathrm{i}}$ after honey exposure, we performed again confocal observations treated with $4 \%$ manuka honey but in a $0 \mathrm{Ca}^{2+}$ condition. The results showed that the entry from the extracellular space was fundamental for the observed $\mathrm{Ca}^{2+}$ peak; however, in the second part of the recording, we noticed a slight increase in the $\left[\mathrm{Ca}^{2+}\right]_{\mathrm{i}}$ compared with the basal one.

It has already been described that the initial $\mathrm{Ca}^{2+}$ rise could be caused by some ROS-sensitive $\mathrm{Ca}^{2+}$ channels such as TRPM2, TRPC5, TRPV1 and TRPA1 [32]; so, by using econazole, we observed a behavior similar to that recorded in $0 \mathrm{Ca}^{2+}$, pointing out that a TRPM2 channel was involved in the initial $\mathrm{Ca}^{2+}$ entry from the extracellular space.

In many cell types, $\mathrm{H}_{2} \mathrm{O}_{2}$ can also stimulate the mobilization of $\mathrm{Ca}^{2+}$ by altering from the ER the $\mathrm{Ca}^{2+}$ release acting on ryanodine receptors [21] and inositol 1,4,5-trisphosphate $\left(\mathrm{IP}_{3}\right)$-dependent $\mathrm{Ca}^{2+}$ channels [33]. Moreover, it is known that $\mathrm{H}_{2} \mathrm{O}_{2}$ activates PLC in some cell types [34] so we explored whether the $\mathrm{PLC} / \mathrm{IP}_{3}$ axis was activated after honey treatment. We characterized the involvement of the $\mathrm{IP}_{3}$ signaling by using a PLC inhibitor, U73122, and an $\mathrm{IP}_{3} \mathrm{R}$ inhibitor, caffeine, observing a significant but non-complete decrease of the $\left[\mathrm{Ca}^{2+}\right]_{\mathrm{i}}$ level.

AQP3 has been recognized as a mediator of $\mathrm{H}_{2} \mathrm{O}_{2}$ uptake and accumulation into the cytosol, which could modify the gating of adjacent $\mathrm{H}_{2} \mathrm{O}_{2}$-sensitive channels [13]. Functional experiments of water permeability demonstrated that the presence of $50 \mathrm{M} \mathrm{H}_{2} \mathrm{O}_{2}$ reduced significantly the AQP permeability, thus limiting its entry into the cell, as previously demonstrated in other cell models $[12,35,36]$. The concentration of $\mathrm{H}_{2} \mathrm{O}_{2}$ was similar to that obtained by manuka honey treatment [2] but, surprisingly, the treatment with manuka honey did not decrease the water permeability. This result may suggest that one or more components of manuka honey maintained the pore completely open even allowing the entry of high concentrations of $\mathrm{H}_{2} \mathrm{O}_{2}$ into the cells and thus leading to cell death even with high concentrations of $\mathrm{H}_{2} \mathrm{O}_{2}$, which normally reduces its permeability.

We observed that the cytotoxic effect of manuka honey is carried out by apoptosis as already proposed [37] through the action of the $\mathrm{H}_{2} \mathrm{O}_{2}$, with a significant reduction of $\Delta \psi \mathrm{M}$ and an increase of the intracellular ROS species while after pre-treatment with CAT, cell viability was preserved.

We also recently revealed in non-cancerous cells [2] that honey caused an overexpression of AQP3 and acted through this protein leading to an increase of intracellular ROS and triggering a variation in $\mathrm{Ca}^{2+}$ signaling. We demonstrated that also in the A431 cell line, honey determined an augmented expression of AQP3, which played a pivotal role in the carry-out of this mechanism even if it cannot be excluded that manuka honey may also act on other AQPs other than AQP3 [35,36]. Therefore, AQP3 facilitated $\mathrm{H}_{2} \mathrm{O}_{2}$ entry into the cytoplasm where it could trigger TRPM2-mediated $\mathrm{Ca}^{2+}$ entry 
from the extracellular space by acting from the cytosolic side. Moreover, as previously described by Huber and colleagues [38], the oxidative stress induced by $\mathrm{H}_{2} \mathrm{O}_{2}$ entry through AQP3, as well as the initial $\mathrm{H}_{2} \mathrm{O}_{2}$-mediated $\left[\mathrm{Ca}^{2+}\right]_{i}$ rise, generated also a $\mathrm{Ca}^{2+}$ release from the ER.

Wang and co-workers [39] demonstrated a TRPM2-Ca ${ }^{2+}-\mathrm{CaMKII-ROS}$ signaling loop that could determine the shift between cell survival or death. They also pointed out that ROS produced or entered in the cytoplasm determined an activation of TRPM2 and a consequent $\mathrm{Ca}^{2+}$ influx, which in turn led to a further intracellular ROS production. Taking into account that intracellular ROS presence and/or the consumption of antioxidant proteins is normally augmented in tumor cells than in normal cells, making tumor cells more sensitive to oxidative stress [40], the proposed mechanism could be considered a positive feedback loop.

Evidence is growing that honey may have the potential to be an anticancer agent through several mechanisms. Here we described for the first time in a cancer cell line a possible mechanism through which honey could induce an alteration in the intracellular ROS and homeostatic balance of $\left[\mathrm{Ca}^{2+}\right]_{\mathrm{i}}$ leading to cell death by apoptosis. This mechanism seems to be enhanced by manuka honey's ability to maintain a high $\mathrm{H}_{2} \mathrm{O}_{2}$ permeability. Thus, the potential anticancer activity of manuka honey may represent a novel tandem mechanism of a channel (AQP3) gating coupled with an $\mathrm{H}_{2} \mathrm{O}_{2}$-mediated apoptosis. Moreover, we also confirmed how an oxidative stress-induced disturbance passes through the alteration of intracellular $\mathrm{Ca}^{2+}$.

\section{Conclusions}

The confirmation of honey mechanisms of action through $\mathrm{H}_{2} \mathrm{O}_{2}-\mathrm{AQP} 3-\mathrm{Ca}^{2+}$ disturbance not only in a keratinocytes cell line as we have previously demonstrated [2] but also to a different extent in an A431 cell line does not diminish but rather encourages proof of the numerous anecdotal data about the health benefits and properties of honey. Taken together, data from in vitro experiments and preliminary in vivo researches are encouraging for using honey in chemo-prevention as well as an adjunct therapy to tumor drugs.

Moreover, honey, a most sustainable food produced naturally, is widely available, inexpensive and has minimal danger of adverse side effects [8]. However, there are still many unanswered questions before its use, i.e., the honey precise composition and properties and its antitumor characteristics may differ with the floral source, climate and honey bee species as well as geographic area and storage.

Therefore, further mechanistic studies (i.e., the involvement of mitochondria in the altered $\left[\mathrm{Ca}^{2+}\right]_{\mathrm{i}}$ buffering and apoptosis induction) as well as prospective randomized controlled clinical trials are a prerequisite to corroborate the antitumor potential of honey before endorsements for its use either alone or as an adjuvant therapy for neoplasm treatment.

Author Contributions: S.M., G.P., M.P., U.L. and E.R. planned the research, made the experiments and analyzed the data. S.M. and E.R. carried out the confocal experiments. U.L. and G.P. performed the aquaporins experiments. S.M. and E.R. conceived the project, designed the research and wrote the manuscript. All authors provided intellectual input. All authors have read and agreed to the published version of the manuscript.

Funding: This work was granted (SM) by University del Piemonte Orientale (Ricerca Locale 2019).

Acknowledgments: We are grateful to students Francesca Pittaluga, Alice Pattaro, Marco Carletto and Gregorio Bonsignore for their help in experiments.

Conflicts of Interest: The authors state that the research was performed in the absence of any commercial or financial relationships that could be considered as a potential conflict of interest.

\section{References}

1. Martinotti, S.; Bucekova, M.; Majtan, J.; Ranzato, E. Honey: An Effective Regenerative Medicine Product in Wound Management. Curr. Med. Chem. 2019, 26, 5230-5240. [CrossRef]

2. Martinotti, S.; Laforenza, U.; Patrone, M.; Moccia, F.; Ranzato, E. Honey-Mediated Wound Healing: $\mathrm{H}_{2} \mathrm{O}_{2}$ Entry through AQP3 Determines Extracellular Ca. Int. J. Mol. Sci. 2019, 20, 764. [CrossRef] 
3. Filipic, B.; Mazija, H. Bee product apiderm royal gel ${ }^{\circledR}$ in pressure injuries and wound care-Case report. MOJ Toxicol. 2017, 3, 44-45. [CrossRef]

4. Tonks, A.; Cooper, R.A.; Price, A.J.; Molan, P.C.; Jones, K.P. Stimulation of TNF-alpha release in monocytes by honey. Cytokine 2001, 14, 240-242. [CrossRef] [PubMed]

5. Fukuda, M.; Kobayashi, K.; Hirono, Y.; Miyagawa, M.; Ishida, T.; Ejiogu, E.C.; Sawai, M.; Pinkerton, K.E.; Takeuchi, M. Jungle honey enhances immune function and antitumor activity. Evid. Based Complement. Alternat. Med. 2011, 2011, 908743. [CrossRef] [PubMed]

6. Erejuwa, O.O.; Sulaiman, S.A.; Wahab, M.S. Effects of honey and its mechanisms of action on the development and progression of cancer. Molecules 2014, 19, 2497-2522. [CrossRef] [PubMed]

7. Pichichero, E.; Cicconi, R.; Mattei, M.; Muzi, M.G.; Canini, A. Acacia honey and chrysin reduce proliferation of melanoma cells through alterations in cell cycle progression. Int. J. Oncol. 2010, 37, 973-981. [CrossRef] [PubMed]

8. Porcza, L.M.; Simms, C.; Chopra, M. Honey and Cancer: Current Status and Future Directions. Diseases 2016, 4, 30. [CrossRef] [PubMed]

9. Waheed, M.; Hussain, M.B.; Javed, A.; Mushtaq, Z.; Hassan, S.; Shariati, M.A.; Khan, M.U.; Majeed, M.; Nigam, M.; Mishra, A.P.; et al. Honey and cancer: A mechanistic review. Clin. Nutr. 2019, 38, 2499-2503. [CrossRef]

10. Bienert, G.P.; Schjoerring, J.K.; Jahn, T.P. Membrane transport of hydrogen peroxide. Biochim. Biophys. Acta 2006, 1758, 994-1003. [CrossRef]

11. Wang, H.; Schoebel, S.; Schmitz, F.; Dong, H.; Hedfalk, K. Characterization of aquaporin-driven hydrogen peroxide transport. Biochim. Biophys. Acta Biomembr. 2020, 1862, 183065. [CrossRef] [PubMed]

12. Medraño-Fernandez, I.; Bestetti, S.; Bertolotti, M.; Bienert, G.P.; Bottino, C.; Laforenza, U.; Rubartelli, A.; Sitia, R. Stress Regulates Aquaporin-8 Permeability to Impact Cell Growth and Survival. Antioxid. Redox Signal. 2016, 24, 1031-1044. [CrossRef]

13. Miller, E.W.; Dickinson, B.C.; Chang, C.J. Aquaporin-3 mediates hydrogen peroxide uptake to regulate downstream intracellular signaling. Proc. Natl. Acad. Sci. USA 2010, 107, 15681-15686. [CrossRef]

14. Ranzato, E.; Boccafoschi, F.; Mazzucco, L.; Patrone, M.; Burlando, B. Role of ERK1/2 in platelet lysate-driven endothelial cell repair. J. Cell Biochem. 2010, 110, 783-793. [CrossRef]

15. Ranzato, E.; Patrone, M.; Mazzucco, L.; Burlando, B. Platelet lysate stimulates wound repair of HaCaT keratinocytes. Br. J. Dermatol. 2008, 159, 537-545. [CrossRef] [PubMed]

16. Ranzato, E.; Magnelli, V.; Martinotti, S.; Waheed, Z.; Cain, S.M.; Snutch, T.P.; Marchetti, C.; Burlando, B. Epigallocatechin-3-gallate elicits $\mathrm{Ca}^{2+}$ spike in MCF-7 breast cancer cells: Essential role of Cav3.2 channels. Cell Calcium 2014, 56, 285-295. [CrossRef]

17. Ranzato, E.; Martinotti, S.; Magnelli, V.; Murer, B.; Biffo, S.; Mutti, L.; Burlando, B. Epigallocatechin-3-gallate induces mesothelioma cell death via $\mathrm{H}_{2} \mathrm{O}_{2}$-dependent T-type $\mathrm{Ca}^{2+}$ channel opening. J. Cell Mol. Med. 2012, 16, 2667-2678. [CrossRef] [PubMed]

18. Grynkiewicz, G.; Poenie, M.; Tsien, R.Y. A new generation of $\mathrm{Ca}^{2+}$ indicators with greatly improved fluorescence properties. J. Biol. Chem. 1985, 260, 3440-3450. [PubMed]

19. Laemmli, U.K. Cleavage of structural proteins during the assembly of the head of bacteriophage T4. Nature 1970, 227, 680-685. [CrossRef]

20. Rahib, L.; Smith, B.D.; Aizenberg, R.; Rosenzweig, A.B.; Fleshman, J.M.; Matrisian, L.M. Projecting cancer incidence and deaths to 2030: The unexpected burden of thyroid, liver, and pancreas cancers in the United States. Cancer Res. 2014, 74, 2913-2921. [CrossRef]

21. Favero, T.G.; Zable, A.C.; Abramson, J.J. Hydrogen peroxide stimulates the $\mathrm{Ca}^{2+}$ release channel from skeletal muscle sarcoplasmic reticulum. J. Biol. Chem. 1995, 270, 25557-25563. [CrossRef]

22. Martinotti, S.; Pellavio, G.; Laforenza, U.; Ranzato, E. Propolis Induces AQP3 Expression: A Possible Way of Action in Wound Healing. Molecules 2019, 24, 1544. [CrossRef] [PubMed]

23. Ranzato, E.; Simona Martinotti, S.; Calabrese, C.M.; Calabrese, G. Role of nutraceuticals in cancer therapy. J. Food Res. 2014, 3, 18. [CrossRef]

24. Dorai, T.; Aggarwal, B.B. Role of chemopreventive agents in cancer therapy. Cancer Lett. 2004, 215, 129-140. [CrossRef] [PubMed] 
25. Martinotti, S.; Calabrese, G.; Ranzato, E. Plant polyphenols and human health. In Polyphenols: Food Sources, Bioactive Properties and Antioxidant Effects; Cobb, D.T., Ed.; Nova Publishers Inc.: Hauppauge, NY, USA, 2014; ISBN 978-1-63117-857-3.

26. Fauzi, A.N.; Norazmi, M.N.; Yaacob, N.S. Tualang honey induces apoptosis and disrupts the mitochondrial membrane potential of human breast and cervical cancer cell lines. Food Chem. Toxicol. 2011, 49, 871-878. [CrossRef] [PubMed]

27. Ghashm, A.A.; Othman, N.H.; Khattak, M.N.; Ismail, N.M.; Saini, R. Antiproliferative effect of Tualang honey on oral squamous cell carcinoma and osteosarcoma cell lines. BMC Complement. Altern. Med. 2010, 10, 49. [CrossRef] [PubMed]

28. Swellam, T.; Miyanaga, N.; Onozawa, M.; Hattori, K.; Kawai, K.; Shimazui, T.; Akaza, H. Antineoplastic activity of honey in an experimental bladder cancer implantation model: In vivo and in vitro studies. Int. J. Urol. 2003, 10, 213-219. [CrossRef] [PubMed]

29. Ranzato, E.; Martinotti, S.; Burlando, B. Epithelial mesenchymal transition traits in honey-driven keratinocyte wound healing: Comparison among different honeys. Wound Repair Regen. 2012, 20, 778-785. [CrossRef]

30. Deng, J.; Liu, R.; Lu, Q.; Hao, P.; Xu, A.; Zhang, J.; Tan, J. Biochemical properties, antibacterial and cellular antioxidant activities of buckwheat honey in comparison to manuka honey. Food Chem. 2018, 252, $243-249$. [CrossRef]

31. Putney, J.W.; Tomita, T. Phospholipase C signaling and calcium influx. Adv. Biol. Regul. 2012, 52, $152-164$. [CrossRef]

32. Bogeski, I.; Kappl, R.; Kummerow, C.; Gulaboski, R.; Hoth, M.; Niemeyer, B.A. Redox regulation of calcium ion channels: Chemical and physiological aspects. Cell Calcium 2011, 50, 407-423. [CrossRef] [PubMed]

33. Hu, Q.; Zheng, G.; Zweier, J.L.; Deshpande, S.; Irani, K.; Ziegelstein, R.C. NADPH oxidase activation increases the sensitivity of intracellular $\mathrm{Ca}^{2+}$ stores to inositol 1,4,5-trisphosphate in human endothelial cells. J. Biol. Chem. 2000, 275, 15749-15757. [CrossRef] [PubMed]

34. Qin, S.; Inazu, T.; Yamamura, H. Activation and tyrosine phosphorylation of p72syk as well as calcium mobilization after hydrogen peroxide stimulation in peripheral blood lymphocytes. Biochem. J. 1995, 308 Pt 1, 347-352. [CrossRef]

35. Laforenza, U.; Pellavio, G.; Marchetti, A.L.; Omes, C.; Todaro, F.; Gastaldi, G. Aquaporin-Mediated Water and Hydrogen Peroxide Transport Is Involved in Normal Human Spermatozoa Functioning. Int. J. Mol. Sci. 2016, 18, 66. [CrossRef]

36. Pellavio, G.; Rui, M.; Caliogna, L.; Martino, E.; Gastaldi, G.; Collina, S.; Laforenza, U. Regulation of Aquaporin Functional Properties Mediated by the Antioxidant Effects of Natural Compounds. Int. J. Mol. Sci. 2017, 18, 2665. [CrossRef] [PubMed]

37. Afrin, S.; Giampieri, F.; Gasparrini, M.; Forbes-Hernández, T.Y.; Cianciosi, D.; Reboredo-Rodriguez, P.; Amici, A.; Quiles, J.L.; Battino, M. The inhibitory effect of Manuka honey on human colon cancer HCT-116 and LoVo cell growth. Part 1: The suppression of cell proliferation, promotion of apoptosis and arrest of the cell cycle. Food Funct. 2018, 9, 2145-2157. [CrossRef]

38. Huber, S.M.; Butz, L.; Stegen, B.; Klumpp, D.; Braun, N.; Ruth, P.; Eckert, F. Ionizing radiation, ion transports, and radioresistance of cancer cells. Front. Physiol. 2013, 4, 212. [CrossRef]

39. Wang, Q.; Huang, L.; Yue, J. Oxidative stress activates the TRPM2-Ca. Biochim. Biophys. Acta Mol. Cell Res. 2017, 1864, 957-967. [CrossRef]

40. Acharya, A.; Das, I.; Chandhok, D.; Saha, T. Redox regulation in cancer: A double-edged sword with therapeutic potential. Oxid. Med. Cell Longev. 2010, 3, 23-34. [CrossRef]

Publisher's Note: MDPI stays neutral with regard to jurisdictional claims in published maps and institutional affiliations. 